\title{
Genetic Testing for Type 2 Diabetes in High-Risk Children: the Case for Primordial Prevention
}

\author{
Jennifer Wessel`, David G Marrero§ \\ ‡ Indiana University, Indianapolis, United States of America \\ $\S$ University of Arizona Schools of Public Health and Medicine, Tucson, United States of America
}

Corresponding author: Jennifer Wessel (wesselj@iu.edu)

Reviewable $\quad \mathrm{v} 1$

Received: 29 Aug 2017 | Published: 04 Sep 2017

Citation: Wessel J, Marrero D (2017) Genetic Testing for Type 2 Diabetes in High-Risk Children: the Case for Primordial Prevention. Research Ideas and Outcomes 3: e20695. https://doi.org/10.3897/rio.3.e20695

\begin{abstract}
Extensive research now demonstrates that lifestyle modification can significantly lower risk of developing type 2 diabetes (T2D) in high-risk adults. In children, the evidence for lifestyle modification is not as robust, but the rapidly rising rate of obesity in children coupled with the substantial difficulty in changing behaviors later in life illuminates the need to implement prevention efforts early in the life course of children. Genetic data can now be used early in the life course to identify children at high-risk of developing T2D before traditional clinical measures can detect the presence of prediabetes; a metabolic condition associated with obesity that significantly increases risk for developing T2D. Such early detection of risk may enable the promotion of "primordial prevention" in which parents implement behavior change for their at risk children. Young children with genetic risk are a novel target population. Here we review the literature on genetic testing for prevention as it relates to chronic diseases and specifically use T2D as a model. We discuss the history of primordial prevention, the need for primordial prevention of T2D and the role genetic testing has in primordial prevention of high-risk families.
\end{abstract}

\section{Keywords}

type 2 diabetes; genetic testing; primordial prevention; children; whole genome sequencing 


\section{The Public Health Challenge: Rising Rates of Obesity and Type 2 Diabetes in Adults and Children}

T2D has become one of the most significant public health crises of our times. Currently $10 \%$ of the U.S. general population has T2D and another $37 \%$ are estimated to have prediabetes (a metabolic abnormality that greatly increases risk for developing T2D) (Benjamin et al. 2017). The single most important predictor of T2D is body mass index (BMI) (Hu et al. 2001), a disturbing fact in that currently $68 \%$ of U.S. adults are overweight or obese (Ogden et al. 2014a). In children, the prevalence of obesity and T2D is rising dramatically (May et al. 2012). Currently $32 \%$ of U.S. children are overweight or obese (Ogden et al. 2014b). High rates of overweight/obesity begin at birth and continue to grow throughout early childhood Ogden et al. 2010. A study representing 7,738 U.S. children followed from kindergarten through $8^{\text {th }}$ grade showed that part of the course of obesity is already established by age 5 and for those children who were overweight in kindergarten, $45 \%$ became obese in the early elementary years (Cunningham et al. 2014). This observation is supported by a study that reported ages 2-6 years is the most critical growth period for prediction of adult obesity (De Kroon et al. 2010). Of importance to this discussion, the effect of genetic variation on obesity begins in childhood and manifests in rapid growth leading to adult obesity (Belsky et al. 2012).

T2D is a slow progressing disease that occurs in genetically predisposed individuals preceded by behaviors (diet and physical activity) established early in life; where $\sim 40 \%$ of the variation in T2D can be explained by genetic factors (Kaprio et al. 1992). The clustering of obesity and T2D has been demonstrated in families who share genetic factors and environments that are known to promote obesity ( $\mathrm{Li}$ et al. 2006). Through the recent successes of genome-wide association studies (GWAS) $>250$ single nucleotide polymorphisms (SNPs) have been robustly associated with T2D (Fuchsberger et al. 2016), T2D traits (Wessel et al. 2015), and BMI (Locke et al. 2015); more SNPs will be identified in the coming years. The combined effects of multiple SNPs results in large effects for obesity in children (OR=2.4) (Belsky et al. 2012) and adults $\left(2.73 \mathrm{~kg} / \mathrm{m}^{2}\right)$ (Speliotes et al. 2010), and T2D in adults ( $O R=2.6)$ (Meigs et al. 2008). Not surprising is the genetic architecture of obesity is very similar in children and adults (Bradfield et al. 2012). Given that the effect of genetic variation on obesity begins in childhood and manifests in rapid growth leading to adult obesity (Belsky et al. 2012); the potential utility of genetic testing, particularly as it applies to children, is its ability to identify risk for diabetes before other clinical markers appear such as excessive weight gain.

\section{The Case for Genetic Testing as a Vehicle to Stimulate Primordial Prevention}

In 1978 Toma Strasser, a cardiovascular epidemiologist at the World Health Organization, first proposed the term "primordial prevention" in an opinion piece about the future of cardiology (Strasser 1978). At the time, an epidemic of risk factors for coronary heart 
disease had occurred in developed countries. Foreseeing the epidemic continuing into other countries, he promoted the idea of preventing precipitating risk factors to decrease the burden on populations and their healthcare systems around the world. Strasser's vision of implementing primordial prevention was to move beyond cardiology and its treatments of heart disease, into screening for the risk factors to promote preventive behaviors at a community and global scale. We suggest that the concept of primordial prevention can be applied to identify children at risk for T2D and promote preventive treatment early in the life course. This concept argues that making parents aware of their child's risk may stimulate them to implement behavior changes that can contribute to risk reduction. Indeed, almost all parents do the best they can to nurture and care for their children.

\section{Lifestyle Modification}

Several studies have successfully demonstrated behavioral interventions that focused on modest weight loss and increased physical activity can significantly reduce risk for developing diabetes in adults with prediabetes (Tuomilehto et al. 2001, Knowler et al. 2002). This holds true for adults with high genetic risk where lifestyle modification has been shown to be effective at lowering their diabetes risk (Delahanty et al. 2012).

Of note, lifestyle modification interventions in children have mixed results on weight loss and no substantial outcomes on diabetes prevention have been evidenced (Bradfield et al. 2012, Oosterhoff et al. 2016). This may reflect the way in which most of these interventions have been implemented; at schools. It has become evident that the potential benefits of school-based interventions on the child can be mitigated by parental influence at home where the child has little or no control over many lifestyle choices. Parents have a persuasive role in their child's dietary and physical activity choices (Lindsay et al. 2006, Savage et al. 2007), particularly in the early years. Indeed, children learn their health behaviors from their family (Novilla et al. 2006) and strong correlations between child and parents behaviors are reported (Sonneville et al. 2012, O'Connor et al. 2010). These studies strongly suggest that in order to be effective, diabetes prevention interventions targeting youth need to activate parents, and not solely the child, as the agents of changing behaviors to reduce children's and ultimately the family's risk. In this context, intervention trials in children younger than five years (Golan et al. 1998, Epstein et al. 2007) compared to school aged children (Campbell et al. 2014) have reported promising results. The evidence that obesity begins early in life suggests interventions need to be performed in families with young children to be successful.

\section{Identifying Individuals at Risk for Type 2 Diabetes}

The ability to distinguish individuals into those who develop T2D and those who do not is based on an individual's risk factors, such as age, gender, BMI, glucose, lipids, and blood pressure (Mann et al. 2010). With the recent successes of GWAS, adding genetic risk factors (i.e. SNPs) to predict T2D has added incremental improvements over traditional risk 
factors (Meigs et al. 2008). However, genetic factors alone can significantly predict incident T2D over the life course (Bollinger et al. 2012, Vassy et al. 2012b, Vassy et al. 2012a, de Miguel-Yanes et al. 2011), before the traditional risk factors develop. This argues for using genetic test results early in the life course so as to initiate adoption of life-long healthy behaviors to delay or prevent obesity and other subclinical metabolic abnormalities that lead to overt T2D. With the increasing prevalence of T2D in children, this is a pressing need.

\section{Call for Research Into the Clinical Utility of Genetic Testing to Engage Families Early in Promoting Healthy Behaviors}

Major advances in genetic technology have decreased costs of genotyping and whole genome sequencing (WGS) exponentially (MacArthur and Lek 2012) making it increasingly cost-effective (Brunham and Hayden 2012, Greeley et al. 2011). In the next few years the cost of sequencing an individual's entire genome will cost less than $\$ 1000$ (Kedes and Campany 2011). In light of the cost of WGS becoming clinically feasible, one could imagine patients entire sequence data available at the point of care for clinicians to make screening and treatment decisions. Providers are increasingly using genomic services (Grant et al. 2009, McCarthy et al. 2013). Pediatricians see genetic testing as the first opportunity to predict and preemptively intervene in the progression of obesity and T2D (Bradfield et al. 2012, Cheng et al. 2008), where gene-environment interactions very early in life have overwhelming effects on development of T2D (Eriksson 2007). Patients and consumers report their motivation for utilizing genetic testing is to increase their certainty of disease risk (Esplen et al. 2007) or to motivate behavior change (Bradfield et al. 2012, Grant et al. 2012, Waxler et al. 2012, Committee On 2013) including individuals at high-risk for T2D (Boerschmann et al. 2010, Grant et al. 2009, McCarthy et al. 2013, Cheng et al. 2008, Eriksson 2007, Flegal et al. 2010, Esplen et al. 2007, Markowitz et al. 2011). Parent's intention for genetic testing is to make health-related decisions for both themselves and for their children (Bradfield et al. 2012, Haga et al. 2012, Harris et al. 2012, Bollinger et al. 2012, O'Daniel and Haga 2011, Tercyak et al. 2011, Hay et al. 2012), even when they understand the limitations and risks, including the benefit of knowing genetic risk to make positive lifestyle changes in their children.

Few studies have been conducted on the clinical utility of genetic risk disclosure to improve patient outcomes. Those conducted report mixed results and are limited to a few diseases and only adults (Marteau et al. 2010). Recently, the first study to focus on T2D risk enrolled 108 high-risk adults who were classified as having high or low genetic risk, or control (Grant et al. 2012). The high risk genetic group received the genetic counseling session positively and reported improvement in their perception of control (Waxler et al. 2012). They also reported significant improvements in motivation to make lifestyle changes and participate in the Diabetes Prevention Program (DPP) lifestyle intervention compared to controls (p's=0.01) (Grant et al. 2012), suggesting genetic risk information can serve as a motivator of behavior change. However high risk participants showed no significant 
difference in actual attendance of the 16 DPP sessions when compared to controls $(p>0.05)$.

The American College of Medical Genetics and the American Academy of Pediatrics revised their policy statement on genetic testing and screening in children (Committee On 2013, Ross et al. 2013). For predictive genetic testing, such as T2D, their recommendations were that the decision to offer genetic testing should be driven by the best interest of the child and for an adult onset disease like T2D should only be offered if intervention initiated in childhood may reduce morbidity or mortality. Therefore as T2D is increasingly being diagnosed in childhood coupled with the rising rates of obesity in childhood predictive genetic testing in high-risk families could offer risk information early enough to intervene.

One population that would be particularly suited for investigating the impact of genetic testing is families with a maternal history of gestational diabetes mellitus (GDM). In many respects the children of women with GDM may inherit a substantial genetic risk for T2D. The prevalence of GDM has been rising, alongside the increases in adult BMI, and currently affects $\sim 14 \%$ of pregnancies (Jovanovic and Pettitt 2001). GDM is perhaps the most potent risk factor for developing T2D in mothers. Up to $70 \%$ of women affected by GDM will develop T2D within 5-10 years (Kim et al. 2002, Vohr and Boney 2008, HungerDathe et al. 2006, Lee et al. 2007). Equally alarming is children exposed to in-utero diabetes are more likely to be larger for gestational age at birth (Wendland et al. 2012, Metzger et al. 2008) and obese in childhood (Crume et al. 2011a, Crume et al. 2011b, Boerschmann et al. 2010). Current estimates suggest up to $40 \%$ of youth exposed to GDM will develop T2D, even after adjusting for BMI, making it the single strongest risk factor for developing T2D in children (Dabelea et al. 1998, Dabelea et al. 2008). The in-utero effects of GDM on developing T2D is not well understood but has been postulated that the hormonal events of pregnancy may represent an initiating event that uncovers individuals genetically susceptible to T2D (Ryan et al. 1995). The increasing rates of obesity and T2D in children and carrying this into adulthood, coupled with GDM exposure, make the children of families with a maternal history of GDM prime candidates for primordial prevention.

Genetic testing can illustrate for parents the relative contribution of their child's behaviors, particularly those associated with excessive weight gain. It is known that approximately $40 \%$ of the risk for developing T2D is attributable to genetics which allows focus on the $60 \%$ that can be attributed to the environment and the role environment plays in developing the condition. This offers the opportunity to promote the prevention of obesity through healthy diet and increased physical activity in young children. Parents learning of their child's elevated genetic risk can serve as an activator to begin making healthy choices about their children's diet, physical activity and weight. For example, parents with a personal history of type 1 diabetes (T1D) have been reported to change their young child's environment (e.g. diet, physical activity) to reduce their child's risk of developing T1D even when the risk factors are not established (Smith et al. 2014). Changing the child's environment ultimately benefits parents as they share similar environments and healthy lifestyle choices. 


\section{Conclusions}

To date no study has examined using children's genetic risk to motivate parents to make changes before the child's lifestyle risk factors have developed. Research is required to reveal how genetic risk information can be used to benefit families by engaging them in actual changes in their diets, physical activity and weight and to maintain a healthy lifestyle.

\section{Acknowledgements}

This work was supported in part by the American Heart Association (15SDG22210003).

David G Marrero's current affiliation is the Department of Health Promotion Sciences, Mel and Enid Zuckerman, University of Arizona, Tucson AZ, USA.

\section{Author contributions}

Jennifer Wessel: Dr. Wessel conceptualized the idea, drafted the initial manuscript, and approved the final manuscript as submitted.

David Marrero: Dr. Marrero refined the idea initially conceived by Dr. Wessel, reviewed and revised the initial manuscript, and approved the final manuscript as submitted.

\section{Conflicts of interest}

The author reports no conflicts of interest in this work.

\section{References}

- $\quad$ Belsky DW, Moffitt TE, Houts R, Bennett GG, Biddle AK, Blumenthal JA, Evans JP, Harrington H, Sugden K, Williams B, Poulton R, Caspi A (2012) Polygenic risk, rapid childhood growth, and the development of obesity: evidence from a 4-decade longitudinal study. Archives of Pediatrics and Adolescent Medicine 166 (6): 515-521. https://doi.org/10.1001/archpediatrics.2012.131

- Benjamin EJ, Blaha MJ, Chiuve SE, Cushman M, Das SR, Deo R, de Ferranti SD, Floyd J, Fornage M, Gillespie C, Isasi CR, Jiménez MC, Jordan LC, Judd SE, Lackland D, Lichtman JH, Lisabeth L, Liu S, Longenecker CT, Mackey RH, Matsushita K, Mozaffarian D, Mussolino ME, Nasir K, Neumar RW, Palaniappan L, Pandey DK, Thiagarajan RR, Reeves MJ, Ritchey M, Rodriguez CJ, Roth GA, Rosamond WD, Sasson C, Towfighi A, Tsao CW, Turner MB, Virani SS, Voeks JH, Willey JZ, Wilkins JT, Wu JH, Alger HM, Wong SS, Muntner P (2017) Heart disease and stroke statistics - 
2017 Update: a report from the American Heart Association. Circulation 135 (10): e146e603. https://doi.org/10.1161/CIR.0000000000000485

- Boerschmann H, Pfluger M, Henneberger L, Ziegler AG, Hummel S (2010) Prevalence and predictors of overweight and insulin resistance in offspring of mothers with gestational diabetes mellitus. Diabetes Care 33 (8): 1845-1849. https://doi.org/10.2337/ dc10-0139

- Bollinger JM, Scott J, Dvoskin R, Kaufman D (2012) Public preferences regarding the return of individual genetic research results: findings from a qualitative focus group study. Genetics in Medicine 14 (4): 451-457. https://doi.org/10.1038/gim.2011.66

- $\quad$ Bradfield JP, Taal HR, Timpson NJ, Scherag A, Lecoeur C, Warrington NM, Hypponen E, Holst C, Valcarcel B, Thiering E, Salem RM, Schumacher FR, Cousminer DL, Sleiman PM, Zhao J, Berkowitz RI, Vimaleswaran KS, Jarick I, Pennell CE, Evans DM, St Pourcain B, Berry DJ, Mook-Kanamori DO, Hofman A, Rivadeneira F, Uitterlinden AG, van Duijn CM, van der Valk RJ, de Jongste JC, Postma DS, Boomsma DI, Gauderman WJ, Hassanein MT, Lindgren CM, Magi R, Boreham CA, Neville CE, Moreno LA, Elliott P, Pouta A, Hartikainen AL, Li M, Raitakari O, Lehtimaki T, Eriksson JG, Palotie A, Dallongeville J, Das S, Deloukas P, McMahon G, Ring SM, Kemp JP, Buxton JL, Blakemore AI, Bustamante M, Guxens M, Hirschhorn JN, Gillman MW, Kreiner-Moller E, Bisgaard H, Gilliland FD, Heinrich J, Wheeler E, Barroso I, O'Rahilly S, Meirhaeghe A, Sorensen TI, Power C, Palmer LJ, Hinney A, Widen E, Faroogi IS, McCarthy MI, Froguel P, Meyre D, Hebebrand J, Jarvelin MR, Jaddoe VW, Smith GD, Hakonarson H, Grant SF (2012) A genome-wide association meta-analysis identifies new childhood obesity loci. Nature Genetics 44 (5): 526-531. https://doi.org/10.1038/ ng.2247

- $\quad$ Brunham LR, Hayden MR (2012) Whole-genome sequencing: the new standard of care? Science 336 (6085): 1112-1113. https://doi.org/10.1126/science.1220967

- Campbell F, Conti G, Heckman JJ, Moon SH, Pinto R, Pungello E, Pan Y (2014) Early childhood investments substantially boost adult health. Science 343 (6178): 1478-1485. https://doi.org/10.1126/science.1248429

- $\quad$ Cheng TL, Cohn RD, Dover GJ (2008) The genetics revolution and primary care pediatrics. JAMA 299 (4): 451-453. https://doi.org/10.1001/jama.299.4.451

- Committee On BNDGSELIC (2013) Ethical and policy issues in genetic testing and screening of children. Pediatrics 131 (3): 620-622. https://doi.org/10.1542/

peds.2012-3680

- $\quad$ Crume TL, Ogden L, Daniels S, Hamman RF, Norris JM, Dabelea D (2011a) The impact of in utero exposure to diabetes on childhood body mass index growth trajectories: the EPOCH study. Journal of Pediatrics 158 (6): 941-946. https://doi.org/10.1016/ j.jpeds.2010.12.007

- $\quad$ Crume TL, Ogden L, West NA, Vehik KS, Scherzinger A, Daniels S, McDuffie R, Bischoff K, Hamman RF, Norris JM, Dabelea D (2011b) Association of exposure to diabetes in utero with adiposity and fat distribution in a multiethnic population of youth: the Exploring Perinatal Outcomes among Children (EPOCH) study. Diabetologia 54 (1): 87-92. https://doi.org/10.1007/s00125-010-1925-3

- Cunningham SA, Kramer MR, Narayan KMV (2014) Incidence of childhood obesity in the United States. New England Journal of Medicine 370 (17): 1660-1661. https:// doi.org/10.1056/NEJMc1402397 
- $\quad$ Dabelea D, Hanson RL, Bennett PH, Roumain J, Knowler WC, Pettitt DJ (1998) Increasing prevalence of type II diabetes in American Indian children. Diabetologia 41 (8): 904-910. https://doi.org/10.1007/s001250051006

- Dabelea D, Mayer-Davis EJ, Lamichhane AP, D'Agostino RBJ, Liese AD, Vehik KS, Narayan KM, Zeitler P, Hamman RF (2008) Association of intrauterine exposure to maternal diabetes and obesity with type 2 diabetes in youth: the search case-control study. Diabetes Care 31 (7): 1422-1426. https://doi.org/10.2337/dc07-2417

- De Kroon ML, Renders CM, Van Wouwe JP, Van Buuren S, Hirasing RA (2010) The Terneuzen birth cohort: BMI changes between 2 and 6 years correlate strongest with adult overweight. PLoS One 5 (2): e9155. https://doi.org/10.1371/journal.pone.0009155

- Delahanty LM, Pan Q, Jablonski KA, Watson KE, McCaffery JM, Shuldiner A, Kahn SE, Knowler WC, Florez JC, Franks PW, Diabetes Prevention Program Research Group (2012) Genetic predictors of weight loss and weight regain after intensive lifestyle modification, metformin treatment, or standard care in the Diabetes Prevention Program. Diabetes Care 35 (2): 363-366. https://doi.org/10.2337/dc11-1328

- de Miguel-Yanes JM, Shrader P, Pencina MJ, Fox CS, Manning AK, Grant RW, Dupuis J, Florez JC, D'Agostino RBS, Cupples LA, Meigs JB (2011) Genetic risk reclassification for type 2 diabetes by age below or above 50 years using 40 type 2 diabetes risk single nucleotide polymorphisms. Diabetes Care 34 (1): 121-125. https:// doi.org/10.2337/dc10-1265

- $\quad$ Epstein LH, Paluch RA, Roemmich JN, Beecher MD (2007) Family-based obesity treatment, then and now: twenty-five years of pediatric obesity treatment. Health Psychology 26 (4): 381-391. https://doi.org/10.1037/0278-6133.26.4.381

- $\quad$ Eriksson JG (2007) Gene polymorphisms, size at birth, and the development of hypertension and type 2 diabetes. Journal of Nutrition 137 (4): 1063-1065. URL: http:// www.ncbi.nlm.nih.gov/pubmed/17374678

- Esplen MJ, Madlensky L, Aronson M, Rothenmund H, Gallinger S, Butler K, Toner B, Wong J, Manno M, McLaughlin J (2007) Colorectal cancer survivors undergoing genetic testing for hereditary non-polyposis colorectal cancer: motivational factors and psychosocial functioning. Clinical Genetics 72 (5): 394-401. https://doi.org/10.1111/ j.1399-0004.2007.00893.x

- $\quad$ Flegal KM, Carroll MD, Ogden CL, Curtin LR (2010) Prevalence and trends in obesity among US adults, 1999-2008. JAMA 303 (3): 235-241. https://doi.org/10.1001/ jama.2009.2014

- Fuchsberger C, Flannick J, Teslovich TM, Mahajan A, Agarwala V, Gaulton KJ, Ma C, Fontanillas P, Moutsianas L, McCarthy DJ, Rivas MA, Perry JR, Sim X, Blackwell TW, Robertson NR, Rayner NW, Cingolani P, Locke AE, Fernandez Tajes J, Highland HM, Dupuis J, Chines PS, Lindgren CM, Hartl C, Jackson AU, Chen H, Huyghe JR, van de Bunt M, Pearson RD, Kumar A, Muller-Nurasyid M, Grarup N, Stringham HM, Gamazon ER, Lee J, Chen Y, Scott RA, Below JE, Chen P, Huang J, Go MJ, Stitzel ML, Pasko D, Parker SC, Varga TV, Green T, Beer NL, Day-Williams AG, Ferreira T, Fingerlin T, Horikoshi M, Hu C, Huh I, Ikram MK, Kim BJ, Kim Y, Kim YJ, Kwon MS, Lee J, Lee S, Lin KH, Maxwell TJ, Nagai Y, Wang X, Welch RP, Yoon J, Zhang W, Barzilai N, Voight BF, Han BG, Jenkinson CP, Kuulasmaa T, Kuusisto J, Manning A, Ng MC, Palmer ND, Balkau B, Stancakova A, Abboud HE, Boeing H, Giedraitis V, Prabhakaran D, Gottesman O, Scott J, Carey J, Kwan P, Grant G, Smith JD, Neale BM, Purcell S, Butterworth AS, Howson JM, Lee HM, Lu Y, Kwak SH, Zhao W, Danesh J, Lam VK, 
Park KS, Saleheen D, So WY, Tam CH, Afzal U, Aguilar D, Arya R, Aung T, Chan E, Navarro C, Cheng CY, Palli D, Correa A, Curran JE, Rybin D, Farook VS, Fowler SP, Freedman BI, Griswold M, Hale DE, Hicks PJ, Khor CC, Kumar S, Lehne B, Thuillier D, Lim WY, Liu J, van der Schouw YT, Loh M, Musani SK, Puppala S, Scott WR, Yengo L, Tan ST, Taylor HAJ, Thameem F, Wilson G,S, Wong TY, Njolstad PR, Levy JC, Mangino M, Bonnycastle LL, Schwarzmayr T, Fadista J, Surdulescu GL, Herder C, Groves CJ, Wieland T, Bork-Jensen J, Brandslund I, Christensen C, Koistinen HA, Doney AS, Kinnunen L, Esko T, Farmer AJ, Hakaste L, Hodgkiss D, Kravic J, Lyssenko V, Hollensted M, Jorgensen ME, Jorgensen T, Ladenvall C, Justesen JM, Karajamaki A, Kriebel J, Rathmann W, Lannfelt L, Lauritzen T, Narisu N, Linneberg A, Melander O, Milani L, Neville M, Orho-Melander M, Qi L, Qi Q, Roden M, Rolandsson O, Swift A, Rosengren AH, Stirrups K, Wood AR, Mihailov E, Blancher C, Carneiro MO, Maguire J, Poplin R, Shakir K, Fennell T, DePristo M, Hrabe de Angelis M, Deloukas P, Gjesing AP, Jun G, Nilsson P, Murphy J, Onofrio R, Thorand B, Hansen T, Meisinger C, Hu FB, Isomaa B, Karpe F, Liang L, Peters A, Huth C, O'Rahilly SP, Palmer CN, Pedersen O, Rauramaa R, Tuomilehto J, Salomaa V, Watanabe RM, Syvanen AC, Bergman RN, Bharadwaj D, Bottinger EP, Cho YS, Chandak GR, Chan JC, Chia KS, Daly MJ, Ebrahim SB, Langenberg C, Elliott P, Jablonski KA, Lehman DM, Jia W, Ma RC, Pollin TI, Sandhu M, Tandon N, Froguel P, Barroso I, Teo YY, Zeggini E, Loos RJ, Small KS, Ried JS, DeFronzo RA, Grallert H, Glaser B, Metspalu A, Wareham NJ, Walker M, Banks E, Gieger C, Ingelsson E, Im HK, Illig T, Franks PW, Buck G, Trakalo J, Buck D, Prokopenko I, Magi R, Lind L, Farjoun Y, Owen KR, Gloyn AL, Strauch K, Tuomi T, Kooner JS, Lee JY, Park T, Donnelly P, Morris AD, Hattersley AT, Bowden DW, Collins FS, Atzmon G, Chambers JC, Spector TD, Laakso M, Strom TM, Bell GI, Blangero J, Duggirala R, Tai ES, McVean G, Hanis CL, Wilson JG, Seielstad M, Frayling TM, Meigs JB, Cox NJ, Sladek R, Lander ES, Gabriel S, Burtt NP, Mohlke KL, Meitinger T, Groop L, Abecasis G, Florez JC, Scott LJ, Morris AP, Kang HM, Boehnke M, Altshuler D, McCarthy MI (2016) The genetic architecture of type 2 diabetes. Nature 536 (7614): 41-47. https://doi.org/10.1038/nature18642

- Golan M, Weizman A, Apter A, Fainaru M (1998) Parents as the exclusive agents of change in the treatment of childhood obesity. The American Journal of Clinical Nutrition 67 (6): 1130-1135. URL: http://www.ncbi.nlm.nih.gov/pubmed/9625084

- $\quad$ Grant R, Hivert M, Pandiscio J, Florez J, Nathan D, Meigs J (2009) The clinical application of genetic testing in type 2 diabetes: a patient and physician survey. Diabetologia 52 (11): 2299-2305. https://doi.org/10.1007/s00125-009-1512-7

- Grant RW, O'Brien KE, Waxler JL, Vassy JL, Delahanty LM, Bissett LG, Green RC, Stember KG, Guiducci C, Park ER, Florez JC, Meigs JB (2012) Personalized genetic risk counseling to motivate diabetes prevention: a randomized trial. Diabetes Care 31 (1): 13-19. https://doi.org/10.2337/dc12-0884

- $\quad$ Greeley SA, John PM, Winn AN, Ornelas J, Lipton RB, Philipson LH, Bell GI, Huang ES (2011) The cost-effectiveness of personalized genetic medicine: the case of genetic testing in neonatal diabetes. Diabetes Care 34 (3): 622-627. https://doi.org/10.2337/ dc10-1616

- Haga SB, O'Daniel JM, Tindall GM, Lipkus IR, Agans R (2012) Survey of US public attitudes toward pharmacogenetic testing. The Pharmacogenomics Journal 12 (3): 197-204. https://doi.org/10.1038/tpj.2011.1 
- Harris ED, Ziniel SI, Amatruda JG, Clinton CM, Savage SK, Taylor PL, Huntington NL, Green RC, Holm IA (2012) The beliefs, motivations, and expectations of parents who have enrolled their children in a genetic biorepository. Genetics in Medicine 14 (3): 330-337. https://doi.org/10.1038/gim.2011.25

- Hay J, Kaphingst KA, Baser R, Li Y, Hensley-Alford S, McBride CM (2012) Skin cancer concerns and genetic risk information-seeking in primary care. Public Health Genomics 15 (2): 57-72. https://doi.org/10.1159/000330403

- Hu FB, Manson JE, Stampfer MJ, Colditz G, Liu S, Solomon CG, Willett WC (2001) Diet, lifestyle, and the risk of type 2 diabetes mellitus in women. New England Journal of Medicine 345 (11): 790-797. https://doi.org/10.1056/NEJMoa010492

- Hunger-Dathe W, Mosebach N, Samann A, Wolf G, Muller UA (2006) Prevalence of impaired glucose tolerance 6 years after gestational diabetes. Experimental and Clinical Endocrinology \& Diabetes 114 (1): 11-17. https://doi.org/10.1055/s-2005-873015

- Jovanovic L, Pettitt DJ (2001) Gestational diabetes mellitus. JAMA 286 (20): 2516-2518. https://doi.org/10.1001/jama.286.20.2516

- Kaprio J, Tuomilehto J, Koskenvuo M, Romanov K, Reunanen A, Eriksson J, Stengard J, Kesaniemi YA (1992) Concordance for type 1 (insulin-dependent) and type 2 (noninsulin-dependent) diabetes mellitus in a population-based cohort of twins in Finland. Diabetologia 35 (11): 1060-1067. https://doi.org/10.1007/BF02221682

- Kedes L, Campany G (2011) The new date, new format, new goals and new sponsor of the Archon Genomics X PRIZE competition. Nature Genetics 43 (11): 1055-1058. https://doi.org/10.1038/ng.988

- Kim C, Newton KM, Knopp RH (2002) Gestational diabetes and the incidence of type 2 diabetes: a systematic review. Diabetes Care 25 (10): 1862-1868. https:// doi.org/10.2337/diacare.25.10.1862

- Knowler WC, Barrett-Connor E, Fowler SE, Hamman RF, Lachin JM, Walker EA, Nathan DM (2002) Reduction in the incidence of type 2 diabetes with lifestyle intervention or metformin. New England Journal of Medicine 346 (6): 393-403. https:// doi.org/10.1056/NEJMoa012512

- Lee AJ, Hiscock RJ, Wein P, Walker SP, Permezel M (2007) Gestational diabetes mellitus: clinical predictors and long-term risk of developing type 2 diabetes: a retrospective cohort study using survival analysis. Diabetes Care 30 (4): 878-883. https://doi.org/10.2337/dc06-1816

- $\quad$ Li JK, Ng MC, So WY, Chiu CK, Ozaki R, Tong PC, Cockram CS, Chan JC (2006) Phenotypic and genetic clustering of diabetes and metabolic syndrome in Chinese families with type 2 diabetes mellitus. Diabetes/Metabolism Research and Reviews 22 (1): 46-52. https://doi.org/10.1002/dmrr.577

- $\quad$ Lindsay AC, Sussner KM, Kim J, Gortmaker S (2006) The role of parents in preventing childhood obesity. The Future of Children 16 (1): 169-186. https://doi.org/10.1353/ foc. 2006.0006

- $\quad$ Locke AE, Kahali B, Berndt SI, Justice AE, Pers TH, Day FR, Powell C, Vedantam S, Buchkovich ML, Yang J, Croteau-Chonka DC, Esko T, Fall T, Ferreira T, Gustafsson S, Kutalik Z, Luan J, Magi R, Randall JC, Winkler TW, Wood AR, Workalemahu T, Faul JD, Smith JA, Hua Zhao J, Zhao W, Chen J, Fehrmann R, Hedman AK, Karjalainen J, Schmidt EM, Absher D, Amin N, Anderson D, Beekman M, Bolton JL, Bragg-Gresham JL, Buyske S, Demirkan A, Deng G, Ehret GB, Feenstra B, Feitosa MF, Fischer K, Goel A, Gong J, Jackson AU, Kanoni S, Kleber ME, Kristiansson K, Lim U, Lotay V, Mangino 
M, Mateo Leach I, Medina-Gomez C, Medland SE, Nalls MA, Palmer CD, Pasko D, Pechlivanis S, Peters MJ, Prokopenko I, Shungin D, Stancakova A, Strawbridge RJ, Ju Sung Y, Tanaka T, Teumer A, Trompet S, van der Laan SW, van Setten J, Van VlietOstaptchouk JV, Wang Z, Yengo L, Zhang W, Isaacs A, Albrecht E, Arnlov J, Arscott GM, Attwood AP, Bandinelli S, Barrett A, Bas IN, Bellis C, Bennett AJ, Berne C, Blagieva R, Bluher M, Bohringer S, Bonnycastle LL, Bottcher Y, Boyd HA, Bruinenberg M, Caspersen IH, Ida Chen YD, Clarke R, Daw EW, de Craen AJ, Delgado G, Dimitriou M, Doney AS, Eklund N, Estrada K, Eury E, Folkersen L, Fraser RM, Garcia ME, Geller F, Giedraitis V, Gigante B, Go AS, Golay A, Goodall AH, Gordon SD, Gorski M, Grabe HJ, Grallert H, Grammer TB, Grassler J, Gronberg H, Groves CJ, Gusto G, Haessler J, Hall P, Haller T, Hallmans G, Hartman CA, Hassinen M, Hayward C, Heard-Costa NL, Helmer Q, Hengstenberg C, Holmen O, Hottenga JJ, James AL, Jeff JM, Johansson A, Jolley J, Juliusdottir T, Kinnunen L, Koenig W, Koskenvuo M, Kratzer W, Laitinen J, Lamina C, Leander K, Lee NR, Lichtner P, Lind L, Lindstrom J, Sin Lo K, Lobbens S, Lorbeer R, Lu Y, Mach F, Magnusson PK, Mahajan A, McArdle WL, McLachlan S, Menni C, Merger S, Mihailov E, Milani L, Moayyeri A, Monda KL, Morken MA, Mulas A, Muller G, Muller-Nurasyid M, Musk AW, Nagaraja R, Nothen MM, Nolte IM, Pilz S, Rayner NW, Renstrom F, Rettig R, Ried JS, Ripke S, Robertson NR, Rose LM, Sanna S, Scharnagl H, Scholtens S, Schumacher FR, Scott WR, Seufferlein T, Shi J, Vernon Smith A, Smolonska J, Stanton AV, Steinthorsdottir V, Stirrups K, Stringham HM, Sundstrom J, Swertz MA, Swift AJ, Syvanen AC, Tan ST, Tayo BO, Thorand B, Thorleifsson G, Tyrer JP, Uh HW, Vandenput L, Verhulst FC, Vermeulen SH, Verweij N, Vonk JM, Waite LL, Warren HR, Waterworth D, Weedon MN, Wilkens LR, Willenborg C, Wilsgaard T, Wojczynski MK, Wong A, Wright AF, Zhang Q, LifeLines Cohort S, Brennan EP, Choi M, Dastani Z, Drong AW, Eriksson P, Franco-Cereceda A, Gadin JR, Gharavi AG, Goddard ME, Handsaker RE, Huang J, Karpe F, Kathiresan S, Keildson S, Kiryluk K, Kubo M, Lee JY, Liang L, Lifton RP, Ma B, McCarroll SA, McKnight AJ, Min JL, Moffatt MF, Montgomery GW, Murabito JM, Nicholson G, Nyholt DR, Okada Y, Perry JR, Dorajoo R, Reinmaa E, Salem RM, Sandholm N, Scott RA, Stolk L, Takahashi A, Tanaka T, Van't Hooft FM, Vinkhuyzen AA, Westra HJ, Zheng W, Zondervan KT, The ADIPOGen Consortium, The AGEN-BMI Working Group, The CARDIOGRAMplusC4D Consortium, The CKDGen Consortium, The GLGC, The ICBP, The MAGIC Investigators, The MuTHER Consortium, The MIGen Consortium, The PAGE Consortium, The ReproGen Consortium, The GENIE Consortium, The International Endogene Consortium, Heath AC, Arveiler D, Bakker SJ, Beilby J, Bergman RN, Blangero J, Bovet P, Campbell H, Caulfield MJ, Cesana G, Chakravarti A, Chasman DI, Chines PS, Collins FS, Crawford DC, Cupples LA, Cusi D, Danesh J, de Faire U, den Ruijter HM, Dominiczak AF, Erbel R, Erdmann J, Eriksson JG, Farrall M, Felix SB, Ferrannini E, Ferrieres J, Ford I, Forouhi NG, Forrester T, Franco OH, Gansevoort RT, Gejman PV, Gieger C, Gottesman O, Gudnason V, Gyllensten U, Hall AS, Harris TB, Hattersley AT, Hicks AA, Hindorff LA, Hingorani AD, Hofman A, Homuth G, Hovingh GK, Humphries SE, Hunt SC, Hypponen E, Illig T, Jacobs KB, Jarvelin MR, Jockel KH, Johansen B, Jousilahti P, Jukema JW, Jula AM, Kaprio J, Kastelein JJ, KeinanenKiukaanniemi SM, Kiemeney LA, Knekt P, Kooner JS, Kooperberg C, Kovacs P, Kraja AT, Kumari M, Kuusisto J, Lakka TA, Langenberg C, Le Marchand L, Lehtimaki T, Lyssenko V, Mannisto S, Marette A, Matise TC, McKenzie CA, McKnight B, Moll FL, Morris AD, Morris AP, Murray JC, Nelis M, Ohlsson C, Oldehinkel AJ, Ong KK, Madden 
PA, Pasterkamp G, Peden JF, Peters A, Postma DS, Pramstaller PP, Price JF, Qi L, Raitakari OT, Rankinen T, Rao DC, Rice TK, Ridker PM, Rioux JD, Ritchie MD, Rudan I, Salomaa V, Samani NJ, Saramies J, Sarzynski MA, Schunkert H, Schwarz PE, Sever P, Shuldiner AR, Sinisalo J, Stolk RP, Strauch K, Tonjes A, Tregouet DA, Tremblay A, Tremoli E, Virtamo J, Vohl MC, Volker U, Waeber G, Willemsen G, Witteman JC, Zillikens MC, Adair LS, Amouyel P, Asselbergs FW, Assimes TL, Bochud M, Boehm BO, Boerwinkle E, Bornstein SR, Bottinger EP, Bouchard C, Cauchi S, Chambers JC, Chanock SJ, Cooper RS, de Bakker PI, Dedoussis G, Ferrucci L, Franks PW, Froguel P, Groop LC, Haiman CA, Hamsten A, Hui J, Hunter DJ, Hveem K, Kaplan RC, Kivimaki M, Kuh D, Laakso M, Liu Y, Martin NG, Marz W, Melbye M, Metspalu A, Moebus S, Munroe PB, Njolstad I, Oostra BA, Palmer CN, Pedersen NL, Perola M, Perusse L, Peters U, Power C, Quertermous T, Rauramaa R, Rivadeneira F, Saaristo TE, Saleheen D, Sattar N, Schadt EE, Schlessinger D, Slagboom PE, Snieder H, Spector TD, Thorsteinsdottir U, Stumvoll M, Tuomilehto J, Uitterlinden AG, Uusitupa M, van der Harst P, Walker M, Wallaschofski H, Wareham NJ, Watkins $H$, Weir DR, Wichmann HE, Wilson JF, Zanen P, Borecki IB, Deloukas P, Fox CS, Heid IM, O'Connell JR, Strachan DP, Stefansson K, van Duijn CM, Abecasis GR, Franke L, Frayling TM, McCarthy MI, Visscher PM, Scherag A, Willer CJ, Boehnke M, Mohlke KL, Lindgren CM, Beckmann JS, Barroso I, North KE, Ingelsson E, Hirschhorn JN, Loos RJ, Speliotes EK (2015) Genetic studies of body mass index yield new insights for obesity biology. Nature 518 (7538): 197-206. https://doi.org/10.1038/nature14177

- MacArthur DG, Lek M (2012) The uncertain road towards genomic medicine. Trends in Genetics 28 (7): 303-305. https://doi.org/10.1016/..tig.2012.05.001

- Mann DM, Bertoni AG, Shimbo D, Carnethon MR, Chen H, Jenny NS, Muntner P (2010) Comparative validity of 3 diabetes mellitus risk prediction scoring models in a multiethnic US cohort: the multi-ethnic study of atherosclerosis. American Journal of Epidemiology 171 (9): 980-988. https://doi.org/10.1093/aje/kwq030

- $\quad$ Markowitz SM, Park ER, Delahanty LM, O'Brien KE, Grant RW (2011) Perceived impact of diabetes genetic risk testing among patients at high phenotypic risk for type 2 diabetes. Diabetes Care 34 (3): 568-573. https://doi.org/10.2337/dc10-1960

- Marteau TM, French DP, Griffin SJ, Prevost AT, Sutton S, Watkinson C, Attwood S, Hollands GJ (2010) Effects of communicating DNA-based disease risk estimates on risk-reducing behaviours. Cochrane Database of Systematic Reviews (10). https:// doi.org/10.1002/14651858.CD007275.pub2

- May AL, Kuklina EV, Yoon PW (2012) Prevalence of cardiovascular disease risk factors among US adolescents, 1999-2008. Pediatrics 129 (6): 1035-1041. https:// doi.org/10.1542/peds.2011-1082

- McCarthy JJ, McLeod HL, Ginsburg GS (2013) Genomic medicine: a decade of successes, challenges, and opportunities. Science Translational Medicine 5 (189): 189sr4. https://doi.org/10.1126/scitransImed.3005785

- $\quad$ Meigs JB, Shrader P, Sullivan LM, McAteer JB, Fox CS, Dupuis J, Manning AK, Florez JC, Wilson PW, D'Agostino RBS, Cupples LA (2008) Genotype score in addition to common risk factors for prediction of type 2 diabetes. New England Journal of Medicine 359 (21): 2208-2219. https://doi.org/10.1056/NEJMoa0804742

- Metzger BE, Lowe LP, Dyer AR, Trimble ER, Chaovarindr U, Coustan DR, Hadden DR, McCance DR, Hod M, Mclntyre HD, Oats JJ, Persson B, Rogers MS, Sacks DA (2008) 
Hyperglycemia and adverse pregnancy outcomes. New England Journal of Medicine 358 (19): 1991-2002. https://doi.org/10.1056/NEJMoa0707943

- $\quad$ Novilla ML, Barnes MD, De La Cruz NG, Williams PN, Rogers J (2006) Public health perspectives on the family: an ecological approach to promoting health in the family and community. Family \& Community Health 29 (1): 28-42. https://

doi.org/10.1097/00003727-200601000-00005

- O'Connor TM, Hughes SO, Watson KB, Baranowski T, Nicklas TA, Fisher JO, Beltran A, Baranowski JC, Qu H, Shewchuk RM (2010) Parenting practices are associated with fruit and vegetable consumption in pre-school children. Public Health Nutrition 13 (1): 91-101. https://doi.org/10.1017/S1368980009005916

- O'Daniel J, Haga SB (2011) Public perspectives on returning genetics and genomics research results. Public Health Genomics 14 (6): 346-355. https://

doi.org/10.1159/000324933

- $\quad$ Ogden CL, Carroll MD, Flegal KM (2014a) Prevalence of obesity in the United States. JAMA 312 (2): 189-190. https://doi.org/10.1001/jama.2014.6228

- $\quad$ Ogden CL, Carroll MD, Kit BK, Flegal KM (2014b) Prevalence of childhood and adult obesity in the United States, 2011-2012. JAMA 311 (8): 806-814. https://

doi.org/10.1001/jama.2014.732

- $\quad$ Ogden CL, Carroll MD, Curtin LR, Lamb MM, Flegal KM (2010) Prevalence of high body mass index in US children and adolescents, 2007-2008. JAMA 303 (3): 242-249. https:// doi.org/10.1001/jama.2009.2012

- $\quad$ Oosterhoff M, Joore M, Ferreira I (2016) The effects of school-based lifestyle interventions on body mass index and blood pressure: a multivariate multilevel metaanalysis of randomized controlled trials. Obesity Reviews 17 (11): 1131-1153. https:// doi.org/10.1111/obr.12446

- $\quad$ Ross LF, Saal HM, David KL, Anderson RR (2013) Technical report: ethical and policy issues in genetic testing and screening of children. Genetics in Medicine 15 (3):

234-245. https://doi.org/10.1038/gim.2012.176

- $\quad$ Ryan EA, Imes S, Liu D, McManus R, Finegood DT, Polonsky KS, Sturis J (1995) Defects in insulin secretion and action in women with a history of gestational diabetes. Diabetes 44 (5): 506-512. https://doi.org/10.2337/diab.44.5.506

- $\quad$ Savage JS, Fisher JO, Birch LL (2007) Parental influence on eating behavior: conception to adolescence. The Journal of Law, Medicine \& Ethics 35 (1): 22-34. https:// doi.org/10.1111/j.1748-720X.2007.00111.x

- $\quad$ Smith LB, Lynch KF, Baxter J, Lernmark B, Roth R, Simell T, Johnson SB, The Teddy Study Group (2014) Factors associated with maternal-reported actions to prevent type 1 diabetes in the first year of the TEDDY study. Diabetes Care 37 (2): 325-31. https:// doi.org/10.2337/dc13-0449

- Sonneville KR, Rifas-Shiman SL, Kleinman KP, Gortmaker SL, Gillman MW, Taveras EM (2012) Associations of obesogenic behaviors in mothers and obese children participating in a randomized trial. Obesity 20 (7): 1449-1454. https://doi.org/10.1038/ oby. 2012.43

- $\quad$ Speliotes EK, Willer CJ, Berndt SI, Monda KL, Thorleifsson G, Jackson AU, Lango Allen $\mathrm{H}$, Lindgren CM, Luan J, Magi R, Randall JC, Vedantam S, Winkler TW, Qi L, Workalemahu T, Heid IM, Steinthorsdottir V, Stringham HM, Weedon MN, Wheeler E, Wood AR, Ferreira T, Weyant RJ, Segre AV, Estrada K, Liang L, Nemesh J, Park JH, Gustafsson S, Kilpelainen TO, Yang J, Bouatia-Naji N, Esko T, Feitosa MF, Kutalik Z, 
Mangino M, Raychaudhuri S, Scherag A, Smith AV, Welch R, Zhao JH, Aben KK, Absher DM, Amin N, Dixon AL, Fisher E, Glazer NL, Goddard ME, Heard-Costa NL, Hoesel V, Hottenga JJ, Johansson A, Johnson T, Ketkar S, Lamina C, Li S, Moffatt MF, Myers RH, Narisu N, Perry JR, Peters MJ, Preuss M, Ripatti S, Rivadeneira F, Sandholt C, Scott LJ, Timpson NJ, Tyrer JP, van Wingerden S, Watanabe RM, White CC, Wiklund F, Barlassina C, Chasman DI, Cooper MN, Jansson JO, Lawrence RW, Pellikka N, Prokopenko I, Shi J, Thiering E, Alavere H, Alibrandi MT, Almgren P, Arnold AM, Aspelund T, Atwood LD, Balkau B, Balmforth AJ, Bennett AJ, Ben-Shlomo Y, Bergman RN, Bergmann S, Biebermann H, Blakemore Al, Boes T, Bonnycastle LL, Bornstein SR, Brown MJ, Buchanan TA, Busonero F, Campbell H, Cappuccio FP, Cavalcanti-Proenca C, Chen YD, Chen CM, Chines PS, Clarke R, Coin L, Connell J, Day IN, den Heijer M, Duan J, Ebrahim S, Elliott P, Elosua R, Eiriksdottir G, Erdos MR, Eriksson JG, Facheris MF, Felix SB, Fischer-Posovszky P, Folsom AR, Friedrich N, Freimer NB, Fu M, Gaget S, Gejman PV, Geus EJ, Gieger C, Gjesing AP, Goel A, Goyette P, Grallert H, Grassler J, Greenawalt DM, Groves CJ, Gudnason V, Guiducci C, Hartikainen AL, Hassanali N, Hall AS, Havulinna AS, Hayward C, Heath AC, Hengstenberg C, Hicks AA, Hinney A, Hofman A, Homuth G, Hui J, IgI W, Iribarren C, Isomaa B, Jacobs KB, Jarick I, Jewell E, John U, Jorgensen T, Jousilahti P, Jula A, Kaakinen M, Kajantie E, Kaplan LM, Kathiresan S, Kettunen J, Kinnunen L, Knowles JW, Kolcic I, Konig IR, Koskinen S, Kovacs P, Kuusisto J, Kraft P, Kvaloy K, Laitinen J, Lantieri O, Lanzani C, Launer LJ, Lecoeur C, Lehtimaki T, Lettre G, Liu J, Lokki ML, Lorentzon M, Luben RN, Ludwig B, Manunta P, Marek D, Marre M, Martin NG, McArdle WL, McCarthy A, McKnight B, Meitinger T, Melander O, Meyre D, Midthjell K, Montgomery GW, Morken MA, Morris AP, Mulic R, Ngwa JS, Nelis M, Neville MJ, Nyholt DR, O'Donnell CJ, O'Rahilly S, Ong KK, Oostra B, Pare G, Parker AN, Perola M, Pichler I, Pietilainen KH, Platou CG, Polasek O, Pouta A, Rafelt S, Raitakari O, Rayner NW, Ridderstrale M, Rief W, Ruokonen A, Robertson NR, Rzehak P, Salomaa V, Sanders AR, Sandhu MS, Sanna S, Saramies J, Savolainen MJ, Scherag S, Schipf S, Schreiber S, Schunkert H, Silander K, Sinisalo J, Siscovick DS, Smit JH, Soranzo N, Sovio U, Stephens J, Surakka I, Swift AJ, Tammesoo ML, Tardif JC, Teder-Laving M, Teslovich TM, Thompson JR, Thomson B, Tonjes A, Tuomi T, van Meurs JB, van Ommen GJ, Vatin V, Viikari J, Visvikis-Siest S, Vitart V, Vogel CI, Voight BF, Waite LL, Wallaschofski H, Walters GB, Widen E, Wiegand S, Wild SH, Willemsen G, Witte DR, Witteman JC, Xu J, Zhang Q, Zgaga L, Ziegler A, Zitting P, Beilby JP, Farooqi IS, Hebebrand J, Huikuri HV, James AL, Kahonen M, Levinson DF, Macciardi F, Nieminen MS, Ohlsson C, Palmer LJ, Ridker PM, Stumvoll M, Beckmann JS, Boeing H, Boerwinkle E, Boomsma DI, Caulfield MJ, Chanock SJ, Collins FS, Cupples LA, Smith GD, Erdmann J, Froguel P, Gronberg H, Gyllensten U, Hall P, Hansen T, Harris TB, Hattersley AT, Hayes RB, Heinrich J, Hu FB, Hveem K, Illig T, Jarvelin MR, Kaprio J, Karpe F, Khaw KT, Kiemeney LA, Krude H, Laakso M, Lawlor DA, Metspalu A, Munroe PB, Ouwehand WH, Pedersen O, Penninx BW, Peters A, Pramstaller PP, Quertermous T, Reinehr T, Rissanen A, Rudan I, Samani NJ, Schwarz PE, Shuldiner AR, Spector TD, Tuomilehto J, Uda M, Uitterlinden A, Valle TT, Wabitsch M, Waeber G, Wareham NJ, Watkins H, Wilson JF, Wright AF, Zillikens MC, Chatterjee N, McCarroll SA, Purcell S, Schadt EE, Visscher PM, Assimes TL, Borecki IB, Deloukas P, Fox CS, Groop LC, Haritunians T, Hunter DJ, Kaplan RC, Mohlke KL, O'Connell JR, Peltonen L, Schlessinger D, Strachan DP, van Duijn CM, Wichmann HE, Frayling TM, Thorsteinsdottir U, Abecasis GR, Barroso I, Boehnke M, Stefansson K, North KE, 
McCarthy MI, Hirschhorn JN, Ingelsson E, Loos RJ (2010) Association analyses of 249,796 individuals reveal 18 new loci associated with body mass index. Nature Genetics 42 (11): 937-948. https://doi.org/10.1038/ng.686

- $\quad$ Strasser T (1978) Reflections on Cardiovascular Disease. Interdisciplinary Science Reviews 3 (3): 225-230. https://doi.org/10.1179/030801878791925921

- Tercyak K, Hensley Alford S, Emmons K, Lipkus I, Wilfond B, McBride C (2011) Parents' attitudes toward pediatric genetic testing for common disease risk. Pediatrics 127 (5): e1288-e1295. https://doi.org/10.1542/peds.2010-0938

- $\quad$ Tuomilehto J, Lindstrom J, Eriksson JG, Valle TT, Hamalainen H, Ilanne-Parikka P, Keinanen-Kiukaanniemi S, Laakso M, Louheranta A, Rastas M, Salminen V, Uusitupa M, Finnish Diabetes Prevention Study Group (2001) Prevention of type 2 diabetes mellitus by changes in lifestyle among subjects with impaired glucose tolerance. New England Journal of Medicine 344 (18): 1343-1350. https://doi.org/10.1056/ NEJM200105033441801

- $\quad$ Vassy JL, Durant NH, Kabagambe EK, Carnethon MR, Rasmussen-Torvik LJ, Fornage M, Lewis CE, Siscovick DS, Meigs JB (2012a) A genotype risk score predicts type 2 diabetes from young adulthood: the CARDIA study. Diabetologia 55 (10): 2604-2612. https://doi.org/10.1007/s00125-012-2637-7

- $\quad$ Vassy JL, DasMahapatra P, Meigs JB, Schork NJ, Magnussen CG, Chen W, Raitakari OT, Pencina MJ, Jamal SM, Berenson GS, Goodman E (2012b) Genotype prediction of adult type 2 diabetes from adolescence in a multiracial population. Pediatrics 130 (5): e1235-e1242. https://doi.org/10.1542/peds.2012-1132

- Vohr BR, Boney CM (2008) Gestational diabetes: the forerunner for the development of maternal and childhood obesity and metabolic syndrome? The Journal of Maternal-Fetal \& Neonatal Medicine 21 (3): 149-157. https://doi.org/10.1080/14767050801929430

- Waxler JL, O'Brien KE, Delahanty LM, Meigs JB, Florez JC, Park ER, Pober BR, Grant RW (2012) Genetic counseling as a tool for type 2 diabetes prevention: a genetic counseling framework for common polygenetic disorders. Journal of Genetic Counseling 21 (5): 684-691. https://doi.org/10.1007/s10897-012-9486-X

- Wendland EM, Torloni MR, Falavigna M, Trujillo J, Dode MA, Campos MA, Duncan BB, Schmidt MI (2012) Gestational diabetes and pregnancy outcomes - a systematic review of the World Health Organization (WHO) and the International Association of Diabetes in Pregnancy Study Groups (IADPSG) diagnostic criteria. BMC Pregnancy and Childbirth 12 https://doi.org/10.1186/1471-2393-12-23

- Wessel J, Chu AY, Willems SM, Wang S, Yaghootkar H, Brody JA, Dauriz M, Hivert MF, Raghavan S, Lipovich L, Hidalgo B, Fox K, Huffman JE, An P, Lu Y, Rasmussen-Torvik LJ, Grarup N, Ehm MG, Li L, Baldridge AS, Stancakova A, Abrol R, Besse C, Boland A, Bork-Jensen J, Fornage M, Freitag DF, Garcia ME, Guo X, Hara K, Isaacs A, Jakobsdottir J, Lange LA, Layton JC, Li M, Hua Zhao J, Meidtner K, Morrison AC, Nalls MA, Peters MJ, Sabater-Lleal M, Schurmann C, Silveira A, Smith AV, Southam L, Stoiber MH, Strawbridge RJ, Taylor KD, Varga TV, Allin KH, Amin N, Aponte JL, Aung T, Barbieri C, Bihlmeyer NA, Boehnke M, Bombieri C, Bowden DW, Burns SM, Chen Y, Chen YD, Cheng CY, Correa A, Czajkowski J, Dehghan A, Ehret GB, Eiriksdottir G, Escher SA, Farmaki AE, Franberg M, Gambaro G, Giulianini F, Goddard WA, Goel A, Gottesman O, Grove ML, Gustafsson S, Hai Y, Hallmans G, Heo J, Hoffmann P, Ikram MK, Jensen RA, Jorgensen ME, Jorgensen T, Karaleftheri M, Khor CC, Kirkpatrick A, Kraja AT, Kuusisto J, Lange EM, Lee IT, Lee WJ, Leong A, Liao J, Liu C, Liu Y, Lindgren 
CM, Linneberg A, Malerba G, Mamakou V, Marouli E, Maruthur NM, Matchan A, McKean-Cowdin R, McLeod O, Metcalf GA, Mohlke KL, Muzny DM, Ntalla I, Palmer ND, Pasko D, Peter A, Rayner NW, Renstrom F, Rice K, Sala CF, Sennblad B, Serafetinidis I, Smith JA, Soranzo N, Speliotes EK, Stahl EA, Stirrups K, Tentolouris N, Thanopoulou A, Torres M, Traglia M, Tsafantakis E, Javad S, Yanek LR, Zengini E, Becker DM, Bis JC, Brown JB, Adrienne Cupples L, Hansen T, Ingelsson E, Karter AJ, Lorenzo C, Mathias RA, Norris JM, Peloso GM, Sheu WH, Toniolo D, Vaidya D, Varma R, Wagenknecht LE, Boeing H, Bottinger EP, Dedoussis G, Deloukas P, Ferrannini E, Franco OH, Franks PW, Gibbs RA, Gudnason V, Hamsten A, Harris TB, Hattersley AT, Hayward C, Hofman A, Jansson JH, Langenberg C, Launer LJ, Levy D, Oostra BA, O'Donnell CJ, O'Rahilly S, Padmanabhan S, Pankow JS, Polasek O, Province MA, Rich SS, Ridker PM, Rudan I, Schulze MB, Smith BH, Uitterlinden AG, Walker M, Watkins H, Wong TY, Zeggini E, Consortium TE, Laakso M, Borecki IB, Chasman DI, Pedersen O, Psaty BM, Shyong Tai E, van Duijn CM, Wareham NJ, Waterworth DM, Boerwinkle E, Linda Kao WH, Florez JC, Loos RJ, Wilson JG, Frayling TM, Siscovick DS, Dupuis J, Rotter JI, Meigs JB, Scott RA, Goodarzi MO, Consortium EP (2015) Low-frequency and rare exome chip variants associate with fasting glucose and type 2 diabetes susceptibility. Nature Communications 6: 5897. https://doi.org/10.1038/ncomms6897 